Article

\title{
Experimental Investigation of the Mechanical and Thermal Behavior of a PT6A-61A Engine Using Mixtures of JETA-1 and Biodiesel
}

\author{
Alberth Renne Gonzalez Caranton ${ }^{1, *} \mathbb{0}$, Vladimir Silva Leal ${ }^{1}$, Camilo Bayona-Roa ${ }^{1} \mathbb{D}$, \\ Manuel Alejandro Mayorga Betancourt ${ }^{1}{ }^{(D)}$, Carolina Betancourt ${ }^{2}$, Deiver Cortina ${ }^{3}$, \\ Nelson Jimenez Acuña ${ }^{4}$ and Mauricio López ${ }^{4}$
}

\section{check for} updates

Citation: Gonzalez Caranton, A.R.; Silva Leal, V.; Bayona-Roa, C.;

Betancourt, M.A.M.; Betancourt, C.; Cortina, D.; Acuña, N.J.; López, M. Experimental Investigation of the Mechanical and Thermal Behavior of a PT6A-61A Engine Using Mixtures of JETA-1 and Biodiesel. Energies 2021, 14, 3282. https://doi.org/10.3390/ en14113282

Academic Editor: T M Indra Mahlia

Received: 20 April 2021

Accepted: 6 May 2021

Published: 4 June 2021

Publisher's Note: MDPI stays neutral with regard to jurisdictional claims in published maps and institutional affiliations.

Copyright: (c) 2021 by the authors. Licensee MDPI, Basel, Switzerland. This article is an open access article distributed under the terms and conditions of the Creative Commons Attribution (CC BY) license (https:/ / creativecommons.org/licenses/by/ $4.0 /)$.
1 Grupo de Investigación en Aprovechamiento Tecnológico de Materiales y Energía GIATME, Universidad ECCI, Cra. 19 No. 49-20, Bogotá 111311, Colombia; vsilval@ecci.edu.co (V.S.L.); cbayonar@ecci.edu.co (C.B.-R.); mmayorgab@ecci.edu.co (M.A.M.B.)

2 Bio D S. A, Dirección de Servicio Técnico, Terminal de Combustibles Sabana Mancilla, Bogotá 253051, Colombia; carolina.betancourt@biodsa.com

3 Terpel S.A, Laboratorio de Calidad, Planta Mansilla, Terminal de Combustibles Sabana Mancilla, Bogotá 253051, Colombia; deiver.cortina@terpel.com

4 Grupo de Investigación en Electrónica y Tecnologías Para la Defensa, TESDA, Escuela de Suboficiales de la Fuerza Aérea Colombiana, ESUFA Fuerza Aérea Colombiana, FAC, Bogotá 111321, Colombia; nelson.jimenez.fac@ecci.edu.co (N.J.A.); mauricio.lopezg@fac.mil.co (M.L.)

* Correspondence: argonzalezc@ecci.edu.co

\begin{abstract}
Biofuels are important additives to conventional fuels in combustion engines of the transport sector, as they reduce atmospheric emissions and promote environmental-friendly production chains. The mechanical and thermal performance of a PT6A-61A engine on a test bench of the Colombian Air Force operating with blends of JETA-1 and Biodiesel up to 25\% volume values of substitution is evaluated in this work. Experimental results show that blends are operationally reliable up to $15 \%$ volume content. In that range, the engine operation is not compromised in terms of response variables. Moreover, experimental properties of fuel blends show that the freezing point-which is the most critical variable, does not comply with aeronautical regulations. The system dynamics are subject to several variations in the test parameters, which mainly affected fuel flow, Inter-Turbine Temperature (ITT), and engine performance. A Principal Component Analysis (PCA) is performed over the experimental results to quantify possible disturbances on the bench measurements. This is based on the fact that the study is restrained to stationary test bench conditions.
\end{abstract}

Keywords: PT6A-61A engine; JETA-1; biodiesel; mechanical behavior; principal component analysis (PCA); experimental fluctuations; fuel blending

\section{Introduction}

Estimations of the aeronautical sector continuous growth demonstrate its positive impact over the global economy. However, $\mathrm{CO}_{2}$ emissions may also increase due to the use of JETA-1 as a conventional aviation fuel [1,2]. Boeing predicted an annual increase of the aeronautical sector of approximately $5 \%$ until 2034, with the consequent contribution to the total global greenhouse gas emissions of around $4 \%$ to $6 \%[3,4]$. Therefore, it becomes important to promote mitigation strategies, such as the adoption of renewable aviation fuels. A type of fuel that provides high energy efficiency and boosts alternative productive chains. Biodiesel is indeed a renewable fuel that is obtained through oil transesterifications in homogeneous [5] and heterogeneous catalysis media [6]. The chemical process uses different feedstocks [7] like palm [8], Jatropha [9], algae, and palmist kernel oil [10], and reaches typical conversion efficiencies of around 99\% having a high selectivity. Biodiesel is a remarkable biofuel that is used as a substitute for conventional fuels [11], due to its high 
chemical compatibility, excellent thermal and calorific properties [12]. It reduces $\mathrm{CO}$ and $\mathrm{CO}_{2}$ emissions in combustion engines [13]. The blending of biodiesel with conventional fuel represents a sustainable pathway in the use of biofuels from biomass [14]. This option has been explored by several authors $[15,16]$, mostly by mixing it with additives such as alcohols to improve the physicochemical properties of blends [17]. However, there is not a consensus about the optimal proportions in blends. This is due to the different configurations and the complexity of the combustion chamber in aircraft engines. Talero et al. $[18,19]$ analyzed the performance and emissions of a J69 engine operating with blends of JETA-1 and biodiesel up 25\% in volume. Although high proportions of ethanol can drastically reduce Flashpoint of fuel blends, additives like ethanol are likely to be used soon [20]. Seyam presents a complete review about the use of different additives as methanol, ethanol, DME, and even hydrogen in hybrid aircraft systems [21].

These biofuels could be biokerosene and FAME from palm kernel oil, but also other bio-oils. Regulatory policies in the use of aviation fuels establish maximum and minimum limits of partial substitution of JETA-1 in aeronautic operations [4]. These ranges allow fostering productive chains for biofuels obtained from biomass, especially in developing countries $[5,6,22,23]$. This is specially written in the series of compromises under the United Nations Framework Convention on Climate Change (UNFCCC) and the established guidelines by the Intergovernmental Panel on Climate Change (IPCC) [7-24]. Palm oil transesterification biodiesel is part of one of the productive chains of renewable sources in Colombia. Currently, the bulk volume of generated oil is devoted to the food industry. A small fraction goes for transportation, which does not conflict with the food supply in the country [10-25]. Being a renewable fuel, biodiesel offers good stability, is sulfur-free, and contains low percentages of nitrogen compounds. It has high chemical compatibility with aviation fuel JETA- 1 because of its aromatics and paraffin contents [11,12,26,27]. In terms of operation, several authors have tested the impact over performance and thermal variables of different turbojet engines using compatible mixtures of biofuels and JETA- 1 . These previous investigations have evaluated dynamic models [13-28] and performed exergy analysis [14-29]. The understanding of the aviation engine dynamics operating off-design conditions is still mandatory to partially substitute the use of fossil fuels.

The PT6A engines are shaft-type power plants which are commonly used in low to middle range aircraft. Mainly, these are used as turboprop engines both in the military and civil sectors. Some specifications of the PT6A engines are shown in Table 1.

The PT6A-61A engine has an axial compressor, a centrifugal compressor, a reverse flow combustion chamber, a gas turbine, and a power turbine [15-30]. The combustion chamber allows high efficiency in fuel consumption [16-31]. The engine has two independent mechanical modules: the Gas Producer $(\mathrm{Ng})$ module which generates combustion, and the Power Producer module related to the propeller motion. The combustion gases drive the respective turbine wheels: one for the gas compression stage and the other for power generation [17-32]. Two reduction boxes are installed in each module to reduce the turbine revolutions. In the power generation turbine wheel, the torque representing Shaft HorsePower (SHP) is multiplied. The accessory section [18-33] is in charge of controlling power through the fuel dosage, according to the operating environment associated with the barometric pressure. Then, controlling the engine response through the pneumatic pressure of the compressor and position throttle [19-34]. A few reported articles demonstrate the state of the art of turboprop-type engine analysis operating at off-design parameters. Mainly by performing a global exergetic analysis [17-32], focused on the performance of the engine in terms of mass balance, energy, but without experimentally validating the analysis over an Aircraft test bench. 
Table 1. PT6A family of engines specifications [18-33].

\begin{tabular}{|c|c|c|}
\hline Model & $\begin{array}{c}\text { Max Mechanical Power } \\
\text { (SHP) }\end{array}$ & $\begin{array}{c}\text { Max Speed Propeller } \\
\text { (RPM) }\end{array}$ \\
\hline PT6A Small & 760 & 2200 \\
\hline PT6A Medium & 1200 & 2000 \\
\hline PT6A Large (A-52 at A-68) & 1700 & 2000 \\
\hline \multicolumn{3}{|c|}{ PT6A-61A Dimensions } \\
\hline Max Height (in) & Max Width (in) & Max Length (in) \\
\hline 25 & 21.9 & 62 \\
\hline 22 & 19.5 & 72 \\
\hline 22 & 19.5 & 76 \\
\hline \multicolumn{3}{|c|}{ PT6A-61A Operation at Sea Level } \\
\hline Variable & Units & Value \\
\hline Shaft & $\mathrm{HP}$ & 850 \\
\hline Jet thrust & $\mathrm{lb}$ & 132 \\
\hline Output & RPM & 2000 \\
\hline Gas generator & RPM & \\
\hline \multicolumn{3}{|c|}{ Takeoff (5 Min) } \\
\hline equivalent shaft & $\mathrm{HP}$ & 902 \\
\hline Jet thrust & $\mathrm{lb}$ & 132 \\
\hline Output & RPM & 2000 \\
\hline Mechanical Power & $\mathrm{HP}$ & 1700 \\
\hline Maximum continuous Power & KW & 634 \\
\hline $\begin{array}{c}\text { Maximum Interstage Turbine } \\
\text { Temperature (ITT) }\end{array}$ & ${ }^{\circ} \mathrm{C}$ & 800 \\
\hline
\end{tabular}

The contribution of the present work lies in the study of the aviation engine performance operation in military facilities since no similar analysis has been evidenced in the specialized literature. The closest references are the works published by Talero et al. [18], in which the operation of turbojet engines are evaluated using mixtures of JETA- 1 and biodiesel up to $5 \%$ mixture by volume. The findings of those authors present an alternative in the use of biofuels in the aeronautical sector for turbojet technologies and motivate the development of this analysis in turboprop engines. As well, recent work on computational simulation was conducted by Bayona-Roa et al. [13-28] in which the dynamic operating conditions of a PT6A-61A engine were simulated using mixtures of JETA- 1 and biodiesel. Based on these previous remarks, this article presents an analysis of a PT6A-61A engine experimental operation in an aviation test bench using mixtures of JETA- 1 and biodiesel. The present findings are also computationally validated, showing the engine response in terms of the engine performance variables.

In terms of engine performance-operating outside design conditions, the present work evaluates the operation using mixtures of biodiesel and JET A-1, maintaining substitution percentages of up to $25 \%$ of biodiesel. The objective is to demonstrate the relationship between the combustion and physicochemical properties of the fuel on the thermal and mechanical behavior of the engine. The organization of this document is as follows. In Section 2 the experimental procedure conducted is described, including the chemical characterization methodology for the experimental fuels and the experimental bench description. In Section 3, the experimental results of the fuel characterization and the evaluation of the PT6A-61A engine operating with JETA mixtures are presented. As well, the statistical treatment of the experimental results are detailed. Finally, in Section 4, some conclusions and future research lines are presented.

\section{Materials and Methods}

This research is conducted under atmospheric conditions at the Madrid-Cundinamarca (Colombia) CAMAN Air Base. The experimental plan is designed over the PT6A-61A 
engine operating in an AM37T-21 stationary test bench. This bench is owned by the Colombian Air Force and is currently used for research activities regarding the substitution of conventional aviation fuel with biofuel mixtures. The test bench has a work capacity of $8000 \mathrm{HP}$ adapted for turboprop aviation engine tests. Thus, allowing the use of the PT6A61A type of engine since its applications worldwide are both military and commercial. Indeed, the PT6A-61A is a general interest type of engine for the international aeronautical sector. The operating limits specified in the manufacturer's operating manual are taken into consideration in the tests. The operating limits specified in the manufacturer's operating manual of the engine are taken into consideration for each operational parameter in the tests. Based on these ranges, an experimental design is achieved by considering the biofuel substitution mixtures, and their respective chemical analysis.

\subsection{Analysis of Biofuel Blends Used for the Tests}

The fuels used in this research are the following: JETA-1, biodiesel, and mixtures of $5 \%, 15 \%$, and $25 \%$ of biodiesel in JETA- 1 . The mixtures are characterized using various techniques that determine the properties of appearance, corrosion to the copper foil, distillation, gums, microseparometer, flash point, freezing point, humidity, total contamination, total sulfur, and aromatics. Additionally, the Higher Heating Value (HHV), the kinematic viscosity, and density of the pure fuels JETA-1 and Biodiesel FAME are measured. These readings are used to predict the properties of the mixtures through Equations (1) and (2), respectively. The transformation of volumetric fractions to mass fractions is conducted with Equation (3) together with the calculation of the density for the ideal mixture of Equation (4).

$$
\begin{gathered}
H H V=\sum w_{i} H H V_{i}=w_{\text {JETA-1 }} H H V_{\text {JETA-1 }}+w_{\text {Biodiesel }} H H V_{\text {Biodiesel }} \\
\ln (\eta)=\sum w_{i} \ln (\eta)_{i}=w_{\text {JETA-1 }} \ln (\eta)_{\text {JETA-1 }}+w_{\text {Biodiesel }} \ln (\eta)_{\text {Biodiesel }} \\
w_{i}=\frac{v_{i} \rho_{i}}{\rho_{\text {ideal }}} \\
\rho_{\text {ideal }}=\sum v_{i} \rho_{i}=v_{\text {JETA-1 }} \rho_{\text {JETA-1 }}+v_{\text {Biodiesel }} \rho_{\text {Biodiesel }}
\end{gathered}
$$

In these equations, $H H V$ is expressed in $\mathrm{MJ} / \mathrm{Kg}, \eta$ is expressed in $\mathrm{mm}^{2} / \mathrm{s}, p$ is expressed in $\mathrm{kg} / \mathrm{m}^{3}$, and $v_{i}, w_{i}$ are dimensionless volumetric and mass fractions, respectively. IR spectroscopy measurements are performed for the mixtures and pure components in a Model BRUKER Alpha equipment with Fourier transform, in the transmittance range of 400 to $4000 \mathrm{~cm}^{-1}$.

\subsection{Evaluation of the PT6-A Engine with the Biodiesel Blends FAME and JETA-1}

The experimental study is conducted by testing the most relevant operating regimes in the mechanical and thermal performance of the PT6A-61A engine. Table 2 shows the measured engine regimes and substitution percentages. Recommended blending operating limits according to international regulations are up to $10 \%$ Biodiesel FAME in JETA-1 [35]. However, up to $25 \%$ biodiesel is used in the experimental tests to evaluate the effect of high percentages of biodiesel over the mechanical parameters and performance of the engine [18]. It has been demonstrated in previous publications that this amount of biodiesel has a considerable impact on the engine operation [19], which is related to the physicochemical properties of biofuel blends. The previous findings over turbojet engines motivate the present experimental design in the turboprop type of engine. 
Table 2. Experimental design of the tests conducted on PT6-A engine.

\begin{tabular}{cc}
\hline Variable & Levels \\
\hline Regimen Engine & Min idle $65 \%$, Transient $75 \%$, Transient $90 \%$, Take off $96 \%$ \\
$0,5,15,25$ \\
\hline
\end{tabular}

The measurements of the engine variables are achieved through different engine speeds. The engine speed is mechanically controlled by using an adapted throttle lever near the test bench. This throttle is manually operated from a control cabin, locating the desired regime at each experimental level within the design, and stabilizing the regime to be able to measure the engine variables. Most variables are read by the avionics instruments. The experimental variables which are measured during the tests together with their respective sensors are shown in Table 3. All these variables are included in the analysis by considering the in-flight operating conditions of the engine and the operation ranges established by the engine manufacturer [31,33].

Table 3. Thermal and mechanical response variables measured on the test bench.

\begin{tabular}{ccc}
\hline Variable & Units & Symbol \\
\hline Torque $(\mathrm{T})$ & Left & $\mathrm{T}$ \\
Prop $\left(\mathrm{N}_{\mathrm{p}}\right)$ & $\mathrm{RPM}$ & $\mathrm{N}_{\mathrm{p}}$ \\
ITT & $\mathrm{o}^{\circ} \mathrm{C}$ & $\mathrm{ITT}$ \\
$\%$ RPM of engine & $\% \mathrm{RPM}$ & $\mathrm{N} / \mathrm{A}$ \\
Fuel flow & $\mathrm{Lb} / \mathrm{h}$ & $\mathrm{F}_{\mathrm{C}}$ \\
Fuel Pressure & $\mathrm{PSI}$ & $\mathrm{P}_{\mathrm{C}}$ \\
\hline Sensor & Range & Accuracy \\
\hline Pressure Transmitter & $0-75 \mathrm{Psi}$ & $\pm 3 \%$ \\
Tachometer Generator & $1600-1900$ & $\pm 1 \%$ \\
Temperature sensor & $1100{ }^{\circ} \mathrm{C}$ & $\pm 1 \%$ \\
Pt-Rh Thermocouples & $\leq 1300{ }^{\circ} \mathrm{C}$ & $\pm 0.8 \%$ \\
Fuel Flow Transmitter & $0-600 \mathrm{Lb} / \mathrm{h}$ & $\pm 0.8 \%$ \\
\hline
\end{tabular}

Figure 1a indicates the engine control mechanism and Figure $1 \mathrm{~b}$ shows a detail of the PT6A-61A engine. The operability and maneuverability of the engine regimes are provided by three levers installed on the test bench indicated: the fuel lever, the power lever, and the propeller lever, which allows the propeller movement during operation and emergency stops.

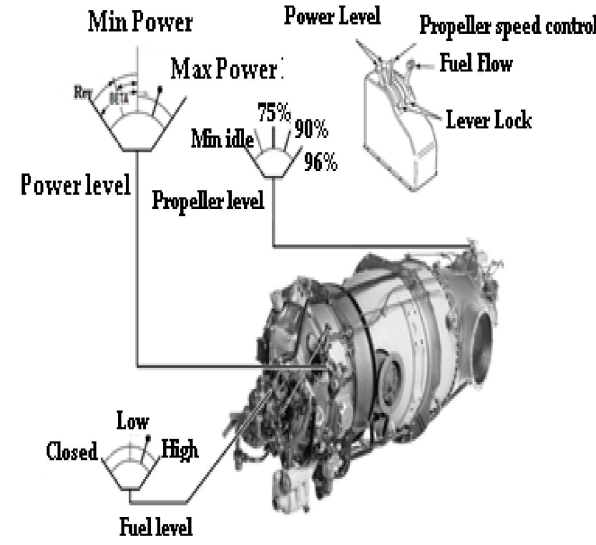

(a)

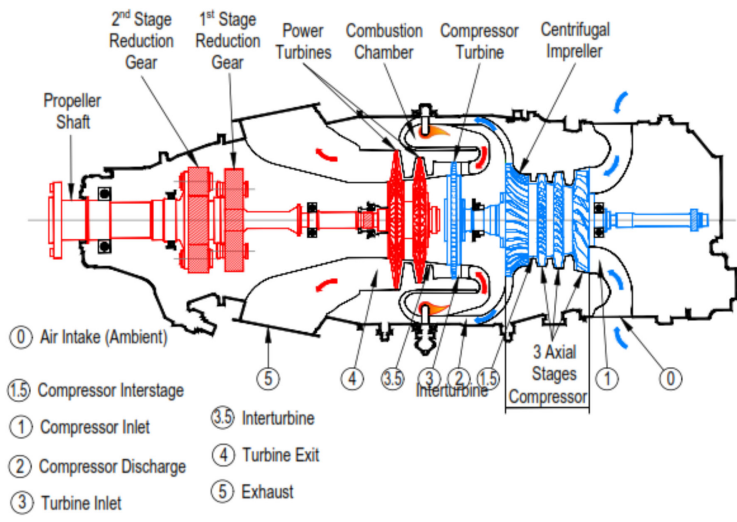

(b)

Figure 1. (a) PT6A-61A engine control mechanism. (b) Detailed schematic of the PT6A-61A engine.

Preliminary tests are conducted to verify the engine ignition using JETA-1. The indicators and instruments installed on the test bench are recorded during the tests. As 
well as the combustion chamber instruments and the pressure manometer, oil temperature, Interstage Turbine Temperature (ITT), torque indication systems, and free rotation speed signals. The \% RPM of the engine determines each operating regime (as given in the operation manual). The fuel supply system is verified before running the tests. All operating procedures, as well as the sensors, controllers, and indicators, are installed and calibrated following the aircraft's certification [36]. The test procedures and protocols used for executing the experiments are, respectively, the Data Sheet E4EA, the Pratt and Whitney operation manual [32], the maintenance manual 3034342 [34], the overhaul 3034343 from the manufacturer [33], the Piper Cheyenne III 761523 aircraft maintenance manual [37], and the Piper Cheyenne III flight operation manual. The state of the supply system is verified before running the tests. The tests are conducted randomly, always verifying that the operating conditions are within the recommended range. As the operating regime increased to the maximum value. All the response variables are tracked while the operating regime increases, keeping constant the testing time intervals to circa $59 \mathrm{~s}$. The delivered shaft work of engine is calculated by using Equation (5).

$$
W=\frac{T N_{P}}{5252}
$$

where $W$ is the shaft work of engine expressed in $\mathrm{HP}, N_{p}$ is the angular velocity of the propeller (RPM), and 5252 is the conversion factor between $\mathrm{Lb} \mathrm{ft}$ and HP.

\subsection{Empirical Models of Engine Operation and Principal Component Analysis}

The experimental data obtained in the tests are adjusted to generate some empirical models, whose purpose is to find an objective function that allows representing the behavior of the experimental data in the expected ranges. The coefficients of the objective function are adjusted using minimization methods. This function is of the form given by equation

$$
y_{B D}=b+\sum_{i}^{n} \lambda_{i i} x_{i}+\sum_{i=1}^{n} \sum_{j=2, j=2, j \geq i} \lambda_{i j} x_{i j}
$$

Normalizing the variables in the $(-1,2)$ interval, we can write the independent variable as

$$
x=\frac{z-\frac{\left(z_{\max }+z_{\min }\right)}{2}}{\frac{\left(z_{\max }+z_{\min }\right)}{2}}
$$

In these expressions, $\mathrm{z}_{\max }$ and $\mathrm{z}_{\min }$ are the extreme values of the variables, $\mathrm{n}$ is the number of independent variables (not to be confused with the kinematic viscosity), $b$ is the independent term, $\kappa_{i i}$, and $\kappa_{i j}$ are the regression coefficients. The maximum number of experiments should be greater than the number of parameters in the model. Finally, additional experiments should be included at the center point of the experimental condition, to include the experimental error at the center point. The development of the empirical model involves regression strategies and the elimination of variables that are not significant. Mainly, through the use of statistical criteria based on the response and its significance. The verification of the model effectiveness aims to test whether it is capable of representing the response within the experimental error or not. Finally, a Principal Component Analysis is applied to the experimental results. This statistical description is done to quantify the direction of the experimental fluctuations as a function of the operating parameters for each regime and their impact on the response variables [38].

\section{Results}

The obtained results are presented in this section. The results are displayed for each operating regime and fuel substitution levels. First, the characterization of the fuel mixtures is demonstrated through the FTIR analyses. Then, the engine behavior at stationary 
conditions on the test bench is exposed. Finally, the experimental results are analyzed in terms of the statistical analysis and some inspection tests on the disassembled engine.

\subsection{Characterisation of the Fuel Blends}

The results of the characterization tests are shown in Table 4. The physicochemical properties of the different mixtures are presented. These have been determined through the tests described in the previous section. 
Table 4. Physicochemical and combustion properties of the fuel blends.

\begin{tabular}{|c|c|c|c|c|c|c|}
\hline Test & ASTM & Units & JETA-1 & $5 \%$ & $15 \%$ & $25 \%$ \\
\hline Appearance & D-4176 & & pale yellow & clear and bright & clear and bright & yellow-orange \\
\hline API & D-1298 & $\mathrm{kg} / \mathrm{m}^{3}$ & 43.3 & 41.1 & 39 & 36.7 \\
\hline Copper Strip Test & D-130 & & $1 \mathrm{a}$ & $1 \mathrm{a}$ & $1 \mathrm{a}$ & 1a \\
\hline Density & D-1298 & $\mathrm{kg} / \mathrm{m}^{3}$ & 809.50 & 817.5 & 823.78 & 829.1 \\
\hline Dist Initial Point & D-86 & ${ }^{O_{0}^{\prime}} \mathrm{C}$ & 125.3 & 153.7 & 135.4 & 157.5 \\
\hline Dist $10 \%$ & D-86 & ${ }^{\circ} \mathrm{C}$ & 155.8 & 175.6 & 177.2 & 179 \\
\hline Dist $50 \%$ & D-86 & ${ }^{\circ} \mathrm{C}$ & 211.3 & 208 & 214.1 & 223.6 \\
\hline Dist $90 \%$ & D-86 & ${ }^{\circ} \mathrm{C}$ & 255.4 & 252.5 & 310 & 330.5 \\
\hline Dist Final & D-86 & ${ }^{\circ} \mathrm{C}$ & 290.6 & 295.9 & 337.1 & 340.2 \\
\hline Rubber materials & D-1319 & $\mathrm{mg} / 100 \mathrm{~mL}$ & & 19.6 & 46 & \\
\hline Microseparometer & D3948 & $\%$ & & 0 & 0 & \\
\hline Flash Point & D2386 & ${ }^{\circ} \mathrm{C}$ & 60.00 & 40 & 41 & 41 \\
\hline Freezing Point & E203-08 & ${ }^{\circ} \mathrm{C}$ & -47 & -20 & -16 & -10 \\
\hline Humidity & D-1298 & $\mathrm{mg} / \mathrm{kg}$ & & 92 & 123 & 126 \\
\hline Total Pollution & & $\mathrm{mg} / \mathrm{kg}$ & & $<6$ & $<6$ & $<6$ \\
\hline Total Sulphur & & $\mathrm{g} / 100 \mathrm{~g}$ & 25 & & & \\
\hline Aromatics & & $\mathrm{mL} / 100 \mathrm{~mL}$ & & & & \\
\hline HHV & D240-14 & $\mathrm{MJ} / \mathrm{kg}$ & 45.41 & $45.12 *$ & $44.54 *$ & $43.96^{*}$ \\
\hline Kinematic viscosity & D445-15 & $\mathrm{mm}^{2} / \mathrm{s}$ & 1.4122 & 1.4995 * & 1.6884 * & 1.8984 * \\
\hline
\end{tabular}

* Predicted values.

The presence of oxygen in the fuel mixture corresponding to the ester group of the added FAME biodiesel can be observed to be the fundamental cause of the physicochemical and functional properties variations [39]. This presence generates changes due to the mixing process, in terms of calorific value and fluidity [40].

Most physicochemical and combustion properties of the mixtures meet the Aeronautical specifications. Nonetheless, that is not the case of the freezing point, whose admissible value is $-47^{\circ} \mathrm{C}$, much too lower than the biodiesel results. Pure JETA-1 already shows a $-47^{\circ} \mathrm{C}$ freezing point. This property raises to $-20{ }^{\circ} \mathrm{C}$ for the $5 \%$ volume of biodiesel blend. With $25 \%$ of biodiesel, the freezing point reaches $-10^{\circ} \mathrm{C}$. Thus, the biodiesel leads to a deviation of this property from aviation fuel regulations [41]. Another important finding is related to the HHV of the mixtures, which decrease slightly as the biodiesel content increases. With 25\% (by volume) of biodiesel in the blend, the calorific value is reduced by $3.2 \%$ against the JETA- 1 reference. Thus, by increasing the proportion of biodiesel, which has a lower calorific value, the fuel decreases its calorific power. A direct consequence of this is that higher fuel consumption is required to maintain the same thermal power of the cycle [42]. Alternatively, the measured viscosity is within the allowed ranges [43] and does not compromise the engine operation. The Biodiesel FAME in the mixture decreases the flashpoint, being closer to the $38^{\circ} \mathrm{C}$ limit value. The pure JETA-1 fuel shows a flashpoint of $60{ }^{\circ} \mathrm{C}$. In the case of the $5 \%$ biodiesel blend, the flashpoint reduces to $40{ }^{\circ} \mathrm{C}$. However, for the $15 \%$ blend, it remains at $41^{\circ} \mathrm{C}$. The presence of fatty acids from FAME Biodiesel mixed with alkanes and isoparafines from JETA-1 reduces these properties, making the mixture more vulnerable to ignition $[44,45]$.

\subsection{FTIR Analysis of the Fuel Blends}

Figure 2 shows the results of the FTIR spectra for the 5 samples of Biodiesel FAME blends with JETA-1. 


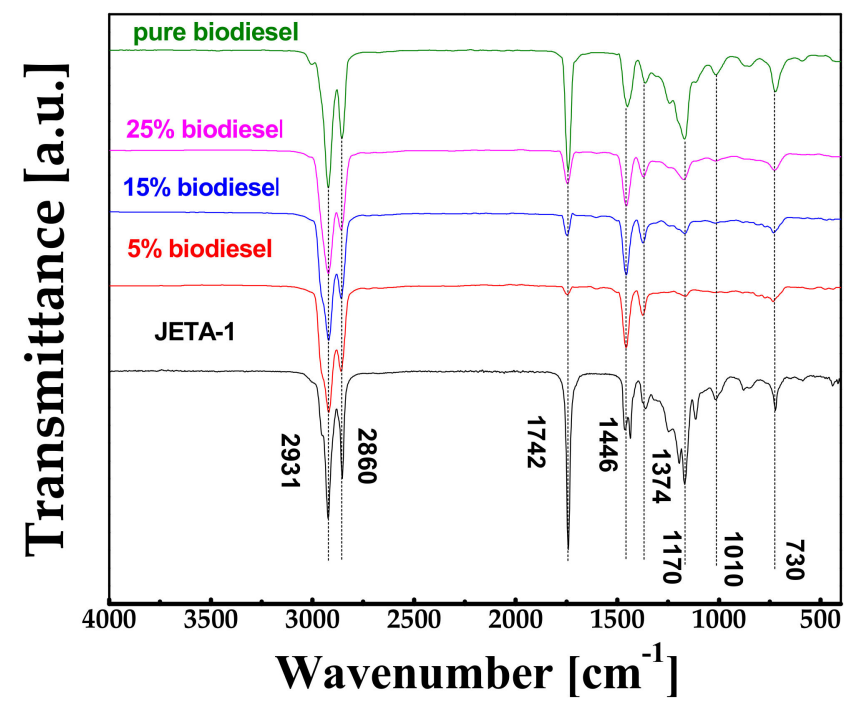

Figure 2. FTIR spectra of JETA-1 and Palm Oil FAME biodiesel blends.

JETA- 1 is composed of branched alkanes between 8 and 16 carbons. Its average molar formula can be expressed as $\mathrm{C}_{11} \mathrm{H}_{21}$ [46-49]. It contains carbon-carbon (C-C) and carbon-hydrogen $(\mathrm{C}-\mathrm{H})$ bonds, showing a $2931 \mathrm{~cm}^{-1}$ stretch associated with a C-H linear stretch and a stronger $\mathrm{C}-\mathrm{H}$ stretch at $2931 \mathrm{~cm}^{-1}$. The peak at $1742 \mathrm{~cm}^{-1}$ corresponds to asymmetric vibrations of the $\mathrm{C}-\mathrm{H}$ bond [50]. As biodiesel is added to JETA-1, it is mixed with the fractions that essentially contain methyl esters $\left(\mathrm{C}_{16}-\mathrm{C}_{18}\right)$ with approximately a composition of $98 \%$ a: $42.8 \%$ palmitic acid $\left(\mathrm{C}_{16} \mathrm{H}_{32} \mathrm{O}_{2}\right), 4.5 \%$ acid stearic $\left(\mathrm{C}_{18} \mathrm{H}_{36} \mathrm{O}_{2}\right)$, $40.5 \%$ oleic acid $\left(\mathrm{C}_{18} \mathrm{H}_{34} \mathrm{O}_{2}\right)$, and $10.1 \%$ linoleic acid $\left(\mathrm{C}_{18} \mathrm{H}_{32} \mathrm{O}_{2}\right)$ [51]. The FAME Biodiesel profile typically presents a C-H bond at $2931 \mathrm{~cm}^{-1}$ related to the alkyl group of the Ester. Subsequently, another peak occurs at $2860 \mathrm{~cm}^{-1}$, related to methyl groups of an asymmetric nature. This is due to the presence of Ester lipids in the three mixtures [52]. The most intense peak for unmixed pure fuels is associated with the carbonyl bond $\mathrm{C}=\mathrm{O}\left(1742 \mathrm{~cm}^{-1}\right)$, indicating the possible presence of ester groups. Other peaks found are at $730 \mathrm{~cm}^{-1}$, $1446 \mathrm{~cm}^{-1}$, and $1374 \mathrm{~cm}^{-1}$, indicating paraffins with methyl-type vibrations [53]. Table 5 summarizes the functional groups found in the different fuel blends between JETA-1 and biodiesel.

Table 5. Spectroscopic information of blends of JETA-1 with biodiesel.

\begin{tabular}{ccc}
\hline Wavenumber $\left(\mathbf{c m}^{-\mathbf{1}}\right)$ & Stretching & Assignment \\
\hline 2931 & C-H Streching (weak) & Alkanes saturated $-\mathrm{CH}_{2}-$ and $-\mathrm{CH}_{3}$ \\
2860 & C-H Streching (strong) & Alkanes saturated $-\mathrm{CH}_{2}-$ and $-\mathrm{CH}_{3}$ \\
1742 & Alkanes saturated $-\mathrm{CH}_{2}-$ and $-\mathrm{CH}_{3}$ \\
1446 & C-H Streching (Asimetric) and C=O Streching & Carbonyl/Carboxyl: $-\mathrm{C}=\mathrm{O}$ \\
1374 & C-H Streching (weak) & Alkanes saturated $-\mathrm{CH}_{2}-$ and $-\mathrm{CH}_{3}$ \\
1170 & C-H Streching (simetric) & Alkanes saturated $-\mathrm{CH}_{2}$ \\
1010 & C-O Streching & ester: $-\mathrm{COO}-$ \\
730 & C-O Streching & ester: - $\mathrm{COO}$ \\
\end{tabular}

The corresponding average molar formulas of blends based on each component concentration and formula are presented in Table 6. The average molar formulas are determined for each mixture through the balance of moles of components. 
Table 6. Semi-empirical analysis and molecular formula of blends.

\begin{tabular}{ccc}
\hline$\% \mathbf{~ V}$ & Empirical Equation & Molecular Weight \\
\hline 0 & $\mathrm{C}_{11} \mathrm{H}_{21}$ & 153.28 \\
5 & $\mathrm{C}_{11 \cdot 2011} \mathrm{H}_{21} \cdot 3968 \mathrm{O}_{0 \cdot 0568}$ & 157.01 \\
15 & $\mathrm{C}_{11 \cdot 6288} \mathrm{H}_{22 \cdot 2408} \mathrm{O}_{0 \cdot 1776}$ & 164.93 \\
25 & $\mathrm{C}_{12 \cdot 0959} \mathrm{H}_{23} \cdot 1625 \mathrm{O}_{0 \cdot 3096}$ & 173.58 \\
100 & $\mathrm{C}_{18 \cdot 08} \mathrm{H}_{34} \cdot 97 \mathrm{O}_{2}$ & 284.40 \\
\hline
\end{tabular}

\subsection{Engine Performance on the Test Bench as a Stationary Operating Condition}

The experimental analysis is done over normalized variables from the experimental data. Table 7 shows the experimental data. To obtain these results each experimental condition has been replicated three times. No variability in the engine temperature, oil pressure, and oil temperature are found. Thus, those variables are neglected in the thermal analysis. In the following analysis we address the engine results operating on the test bench. Especially, the PT6A-61A engine operation is compared against the maximum conditions established by the manufacturer for each measured variable. These analyses are valid for low operation altitudes of aircraft, but invalid for high altitude operation (such as civil aviation).

Table 7. Matrix of experiments with thermal and mechanical measurements.

\begin{tabular}{|c|c|c|c|c|c|}
\hline \multicolumn{2}{|c|}{ Variable Inlet } & \multicolumn{4}{|c|}{ Measured Variables } \\
\hline Stage & $\%$ Biodiesel & Torque $(\mathrm{Lb} / \mathrm{ft})$ * & $\mathbf{N}_{\mathrm{p}}(\mathrm{RPM}) *$ & $\operatorname{ITT}\left({ }^{\circ} \mathrm{C}\right) *$ & Fuel Flow $\left(\mathrm{ft}^{3} / \mathrm{h}\right)$ * \\
\hline Min idle low $63 \%$ & $0 \%$ & 53.3 & 1350.0 & 543.3 & 126.3 \\
\hline Transient 75\% & $0 \%$ & 145.0 & 1616.7 & 553.3 & 156.7 \\
\hline Transient $90 \%$ & $0 \%$ & 841.7 & 1963.3 & 633.3 & 277.7 \\
\hline Take off $96 \%$ & $0 \%$ & 1608.3 & 1996.7 & 726,7 & 398.3 \\
\hline Min idle low $63 \%$ & $5 \%$ & 50.3 & 1300.0 & 553.3 & 120.0 \\
\hline Transient 75\% & $5 \%$ & 151.7 & 1600.0 & 563.3 & 155.0 \\
\hline Transient $90 \%$ & $5 \%$ & 833.3 & 1973.3 & 626.7 & 260.0 \\
\hline Take off $96 \%$ & $5 \%$ & 1603.3 & 1933.3 & 733.3 & 401.7 \\
\hline Min idle low $63 \%$ & $15 \%$ & 25.0 & 1291.7 & 570.0 & 128.3 \\
\hline Transient 75\% & $15 \%$ & 150.0 & 1611.7 & 580.0 & 141.7 \\
\hline Transient $90 \%$ & $15 \%$ & 821.7 & 1993.3 & 639.0 & 311.7 \\
\hline Take off $96 \%$ & $15 \%$ & 1601.6 & 1990.0 & 746.6 & 400 \\
\hline Min idle low $63 \%$ & $25 \%$ & 22.7 & 1286.7 & 580.66 & 120.0 \\
\hline Transient 75\% & $25 \%$ & 150.0 & 1583.3 & 590.66 & 155.0 \\
\hline Transient $90 \%$ & $25 \%$ & 860.0 & 1990.0 & 640.0 & 280.0 \\
\hline Take off $96 \%$ & $25 \%$ & 1623.3 & 1996.6 & 787.66 & 400.0 \\
\hline
\end{tabular}

* Mean values.

Figure $3 \mathrm{a}, \mathrm{b}$ show the delivered torque of the engine. Plots are presented against the operating regime and the percentage of substitution of biodiesel. The torque dependence over the operating regime can be observed in these figures: the "Take off" regime is the most demanding for the engine [54].

The torque measurements indicate power losses due to the use of biodiesel with JETA-1 [31]. Reference JETA-1 operation decreases to $87 \%$ when adding biodiesel content to the fuel. The upper limits of torque delivery are obtained using the $25 \%$ biodiesel mixture. In the case of the flashpoint, it decreases regarding pure JETA-1 [55], producing a variability of the experimental results. Mainly, at higher power regimes ( $90 \%$ and Takeoff) for which greater dispersion of the results is observed at low levels of biodiesel substitution. Figure $3 \mathrm{a}, \mathrm{b}$ show that even with $5 \%$ of biodiesel the torque delivery remained high [56] with minimal variations in calorific power compared to pure JETA-1. The effect of Biodiesel in the delivered torque is evidenced for transient conditions and high operation regimes. A decrease of the torque as a function of the \% of biodiesel is thus observed. This small variation is attributed to the reduction of the calorific value of the mixture as Biodiesel 
is added. Indeed, the HHV decreases as the \% of biodiesel increases. It has also the effect of decreasing the revolutions of the engine. However, the torque stabilizes for high substitution values.

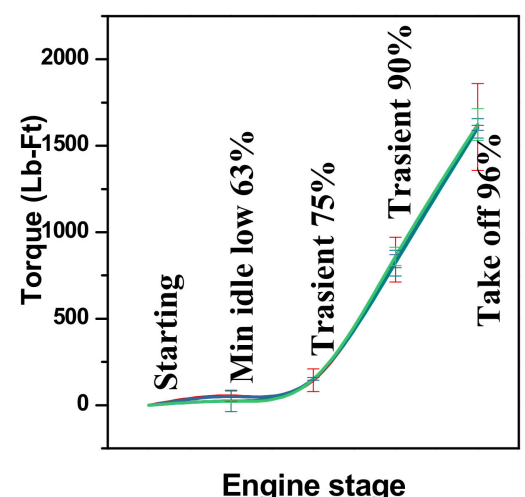

(a)

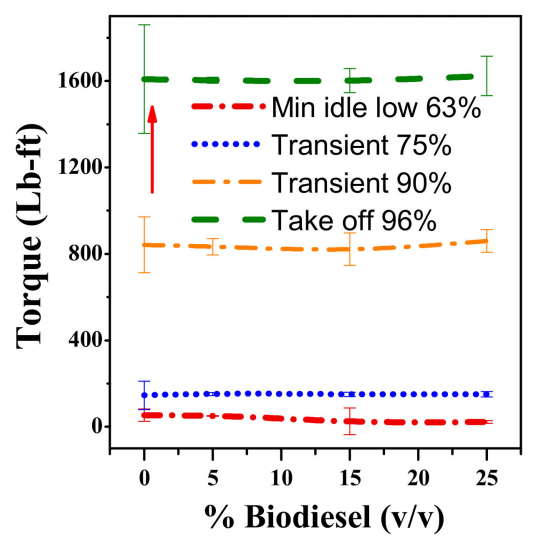

(b)

Figure 3. Engine delivered torque: (a) Depending on the operating regime, (b) depending on the \% of biodiesel.

Figure 4 shows the effect of biodiesel on the rotation speed. Usually, the rotational speed increases as more power is delivered by the fuel [57]. In the present results, the biodiesel impact becomes noticeable during Takeoff, when the engine reaches 2000 RPM. Indeed, a noticeable effect of biodiesel on the engine speed is also appreciated in the idle and $75 \%$ regimes. A drop in $\mathrm{N}_{\mathrm{p}}$ occurs for these regimes, while no variations are observed for the $90 \%$ transient regime. This can be associated with the fact that the HHV decreases with the addition of biodiesel. That is due to the molecular presence of fatty acids that alter the chemical composition and its exergetic efficiency [58]. As shown in Table 6, the content of $\mathrm{C}, \mathrm{H}$, and $\mathrm{O}$ increase for high substitution values. Thus, having an impact on the energy contribution of the fuel $[59,60]$.

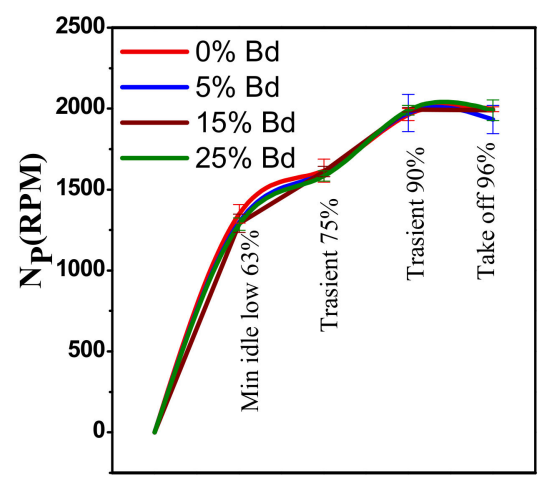

Engine Stage

(a)

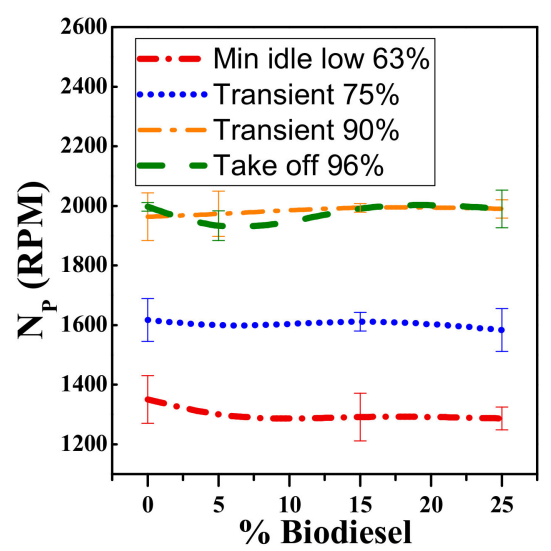

(b)

Figure 4. Engine revolutions (Np): (a) Depending on the operating regime, (b) depending on the \% of biodiesel.

In all cases, an adequate response of the engine is found. This demonstrates the viability of the partial substitution of biodiesel in JETA-1. In terms of the propeller RPM, these results show that adding biodiesel minimally affects the engine operation [28]. For the reverse condition, the propeller revolutions are between 1900 and 2000 RPM [61]. Since these conditions are the operation limit of the propeller, at transient conditions the variability is minimal. This is due to the fluid dynamics of the system. 
Figure 5 shows the ITT $\left({ }^{\circ} \mathrm{C}\right)$ as a function of the engine speed and the $\%$ of biodiesel in the blend. The thermal conditions in the middle $63 \%$ and subsequent $70 \%$ regimes are similar, indicating that the combustion kinetics is related and dependent on the engine starting procedure from cold conditions. No result exceeds the maximum temperature recommended by the manufacturer's manual of $820^{\circ} \mathrm{C}$ [34].

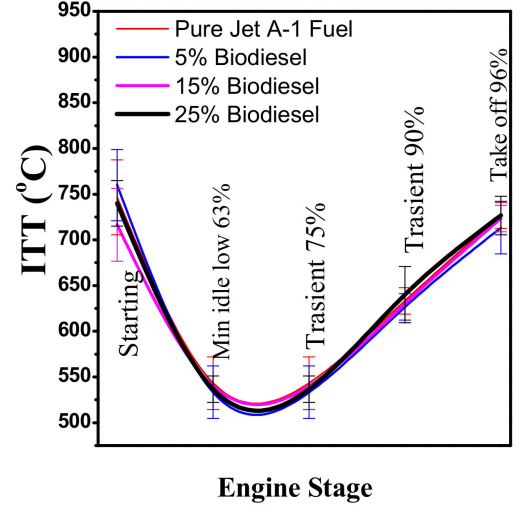

(a)

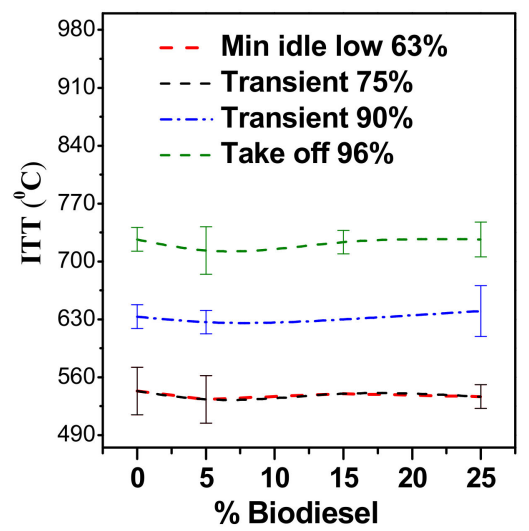

(b)

Figure 5. ITT: (a) Depending on the operating regime, (b) depending on the \% of biodiesel.

The largest error occurs with pure JETA- 1 operation, which could be due to the data collection a few thousandths of seconds before stabilization for the minimum Idle condition. In that case, the temperature remains constant and does not present large changes for any percentages of biodiesel. In the case of the min Idle-High condition, the stabilization temperature is between 550 and $600{ }^{\circ} \mathrm{C}$. Here, it is observed that the temperature reaches admissible values within the operating ranges. Finally, in $90 \%$ and $96 \%$ conditions, a maximum temperature of $750{ }^{\circ} \mathrm{C}$ is reached. Considering that the maximum condition is $880^{\circ} \mathrm{C}$, this value is admissible within the operational ranges. Under the Take-off condition, it is also observed that the biodiesel content has a minimal impact on the central tendency of the ITT measurements, unlike the starting condition, a condition in which an increase in temperature is evidenced for mixtures close to $5 \%$ biodiesel substitution. ITT's paraboliclooking trend can be attributed to the propeller's cooling effects, which become noticeable as the operating regime increases and with it the RPM. At low RPM levels (such as starting), the engine temperature tends to increase due to a reduction in convection heat transfer, while at high operating speeds the effect of heat rejected due to combustion increases by overcoming engine cooling. Therefore, the temperature increases [62].

Figure 6 shows the profiles for fuel consumption, which slightly varies as a function of the $\%$ of biodiesel.

Especially, for the Takeoff and Min Idle 63\% conditions. In the maximum condition, the variability is minimal due to the combustion conditions of the engine. These conditions require high and constant fuel consumption. Some maximums with $15 \%$ substitution are found. They are interpreted as a point of maximum delivery of caloric energy of fuel blend in this condition. The effect of the biodiesel content up to $15 \%$ reveals a significant variation in the fuel flow variable for the Transient $75 \%$ and $90 \%$ regimes as the absolute percent variation is above $7.5 \%$ and $4 \%$, respectively. On the other hand, no significant statistical difference is found in the Min Idle and Take off regimes for the $15 \%$ biodiesel content, with a level of significance of $95 \%$. Another observation is that the rise in the biodiesel content from $0 \%$ to $25 \%$ has no impact on the fuel flow at every operation, mainly explained by the engine control given by the Fuel Control Unit (FCU). Nevertheless, the lower energy content of the biodiesel, poor atomization of the fuel, and possible saturation of the fuel filters may be affecting the measurement of this variable. Finally, the Takeoff condition is a condition of higher fuel consumption. In that case, a high supply of the mixture must provide the energy delivered by the engine. The consumption hence increases as a 
stable Take off condition is established, where the variability in fuel consumption observed is minimal.

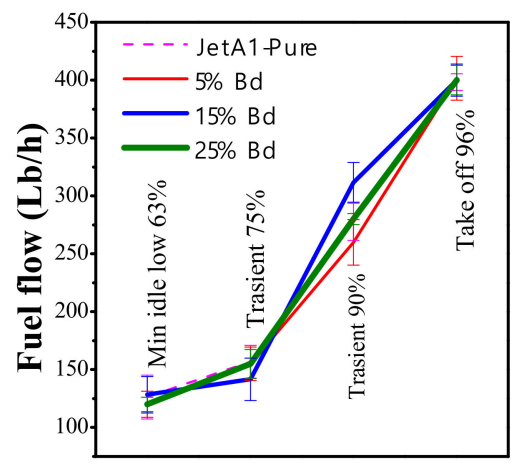

(a)

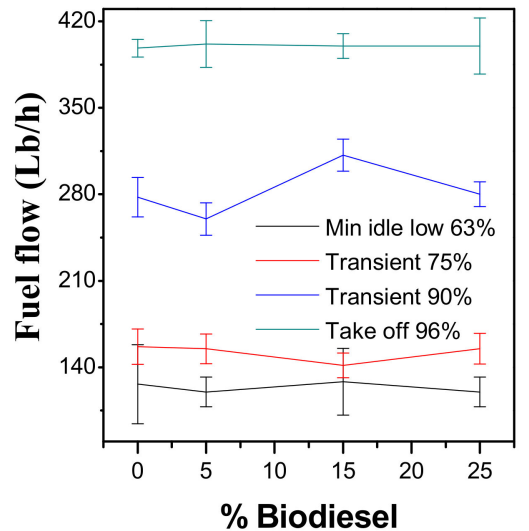

(b)

Figure 6. Fuel flow: (a) Depending on the operating regime, (b) depending on the $\%$ of biodiesel.

Results of the delivered shaft work (See Figure 7) are explained next. Indeed, shaft work is maximum at 5\% biodiesel content and transient conditions of $90 \%$ and $96 \%$ regimes. This indicates that the losses or irreversibility are lower under these conditions: on the one hand, the content of fatty acids increases as biodiesel is added to JETA-1 and, on the other hand, having isoparaffins in a smaller proportion reduces the net heat of combustion [60]. The HHV of the mixture reduces as saturated C compounds and methyl esters increase. Simultaneously, the transport properties for the mixtures increase. Thus, having an impact on the fluid dynamics of the gases during combustion.

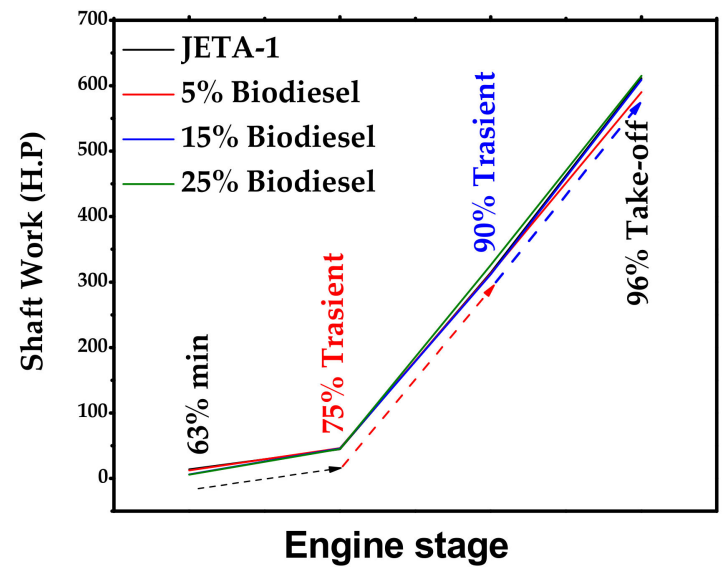

Figure 7. Shaft work delivered on PT6A-61A engine during experimental tests with JETA-1 and biodiesel blends.

As expected, in the Take off and 25\% biodiesel condition, a higher engine shaft work occurs. That contrasts with the results of propeller revolutions delivered in Figure 4. It is also clear that the delivered engine shaft work never exceeds the engine limits. Especially in the cruise condition. No significant variations regarding the biodiesel substitution are found in the engine operation on the test bench.

\subsection{Statistical Analysis of the Mechanical and Thermal Performance of the PT6A-61A Engine}

The experimental data are analyzed in terms of their correlations. Indeed, the correlation matrix of the experimental data is the departure step. Correlations between the measured and manipulated variables of the system can be observed. Table 8 shows this correlation matrix. 
Table 8. Correlation matrix of experimental data as a function of input parameters.

\begin{tabular}{ccccccc}
\hline & Engine Stage & \% Biodiesel & Torque & $\mathbf{N}_{\mathbf{p}}$ & ITT & FF \\
\hline Engine stage & 1.00 & 0.00 & 0.79 & 0.71 & 0.83 & 0.88 \\
\% biodiesel & 0.00 & 1.00 & -0.06 & -0.07 & -0.05 & -0.05 \\
Torque & 0.79 & -0.06 & 1.00 & 0.86 & 1.00 & 0.99 \\
$\mathrm{~N}_{\mathrm{p}}$ & 0.71 & -0.07 & 0.84 & 1.00 & 0.86 & 0.89 \\
ITT & 0.78 & -0.05 & 1.00 & 0.84 & 1.00 & 0.99 \\
FF & 0.79 & -0.05 & 0.99 & 0.89 & 0.99 & 1.00 \\
\hline
\end{tabular}

The highest correlations are between the ITT variable and fuel flow. This demonstrates a strong impact on the operation performance. It also indicates that an increase in revolutions of the engine occurs by the kinetics of combustion and, consequently, the consumption of required fuel. Additionally, the $\%$ of biodiesel has a minimal influence on the measured variables. Considering the highlighted correlations in the correlation matrix, it is possible to obtain empirical models of ITT and fuel consumption as a function of the RM variable (Operating Regime). This procedure categorizes these variables in terms of regimes. Mostly from 65 to $96 \%$ Take-off regimes. Some preliminary investigations have considered empirical models in terms of the $\%$ of biodiesel. However, these models did not show a valid statistical behavior of the dynamic performance of the system. In the ITT case, Table 9 lists the statistical parameters calculated with a proposed linear model of the form:

$$
\operatorname{ITT}(R M)=\lambda_{0}+\lambda_{1} \mathrm{RM}+\lambda_{2} \mathrm{RM}^{2} I T T
$$

Table 9. Statistical model for ITT experimental data.

\begin{tabular}{cccc}
\hline & $\kappa_{\mathbf{0}}$ & $\kappa_{\mathbf{1}}$ & $\kappa_{\mathbf{2}}$ \\
\hline Estimate & 560.0833 & 39.83336 & 10.83334 \\
Std. Err. & 17.9182 & 16.20764 & 12.08046 \\
t (13) & 31.2578 & 2.45769 & 0.89677 \\
p-level & 0.0000 & 0.02879 & 0.38615 \\
\hline
\end{tabular}

Parameters are not significant for p-level values above 0.06 . Hence, by adjusting the data and eliminating the $\kappa_{2}$ parameter, we obtain the statistical model shown in Table 10. These models allow predicting and correcting the measured variables.

Table 10. Experimental data of the second adjustment for ITT.

\begin{tabular}{ccc}
\hline & $\kappa_{\mathbf{0}}$ & $\kappa_{\mathbf{1}}$ \\
\hline Estimate & 569.8085 & 49.33866 \\
Std. Err. & 10.8404 & 9.88382 \\
$\mathrm{t}(14)$ & 52.5633 & 4.99186 \\
p-level & 0.0000 & 0.00020 \\
\hline
\end{tabular}

Figure 8 displays the ITT empirical model. It can be observed that the assumption of the normally distributed error hypothesis is valid, although some residual values of some experiments do not follow the normal distribution. The model seems to accurately fit the experimental data. 


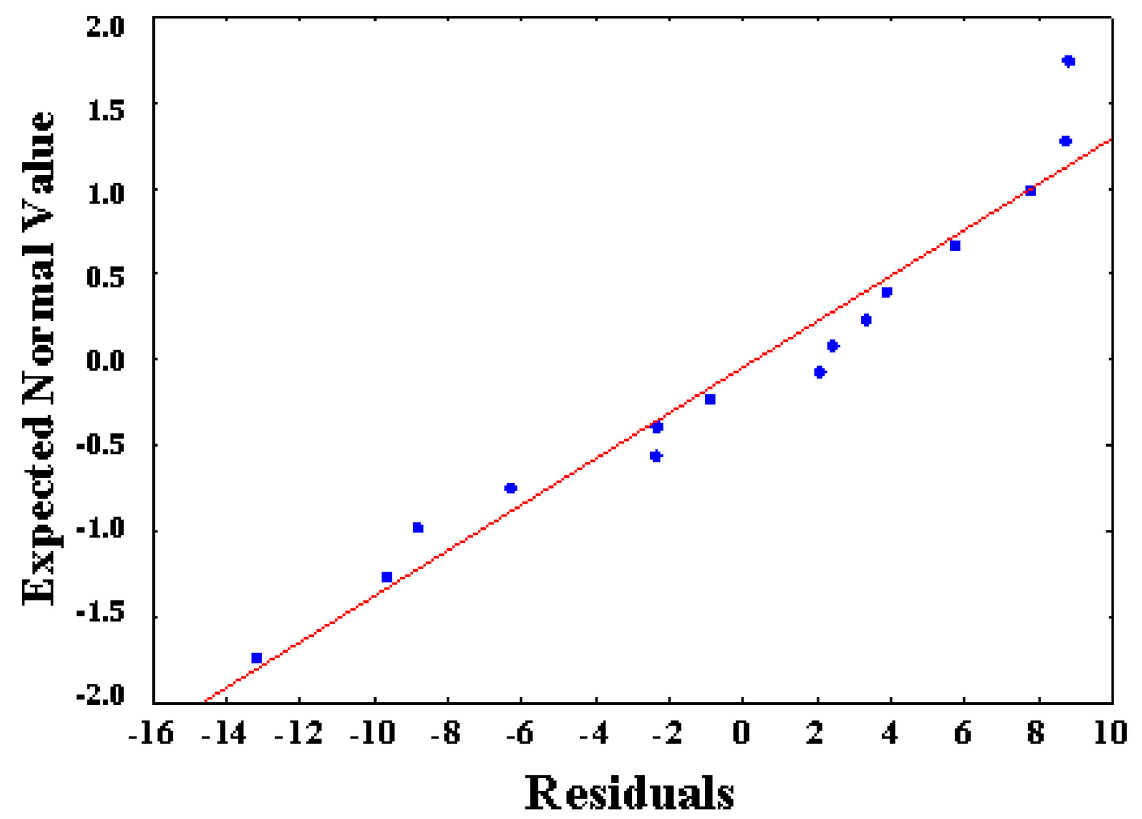

Figure 8. Adjustment of the empirical model obtained of ITT.

The last point in Figure 8 is run 16 of Table 7: Takeoff 96\% with 25\% biodiesel, a condition which can be considered as an outlier and that is likely to present high variability. That condition affects the distribution of residuals, since it contains the highest percentage of biodiesel and represents the most chaotic condition of the engine in operation.

Furthermore, a deeper analysis can be the principal component analysis (PCA) on the experimental replicas. This analysis gives insights into the variations in the test parameters during the engine performance. That analysis aids understanding and quantifying fluctuations [38], which in theory are more marked in transitory operating regimes. Explained by the vibrations increase of the bank that affects the other measured variables. Table 11 shows the PCA of the experimental data.

Table 11. PCA of the experimental data.

\begin{tabular}{|c|c|c|c|c|c|c|}
\hline & \multicolumn{3}{|c|}{$65 \%$ Idle } & \multicolumn{3}{|c|}{$75 \%$ Transient } \\
\hline & Factor 1 & Factor 2 & Factor 3 & Factor 1 & Factor 2 & Factor 3 \\
\hline $\mathrm{T}$ & 0.953324 & 0.300794 & 0.026369 & 0.491719 & -0.853920 & -0.170390 \\
\hline $\mathrm{N}_{\mathrm{p}}$ & 0.429724 & -0.900540 & -0.066066 & -0.974186 & -0.189901 & -0.122062 \\
\hline ITT & -0.882523 & -0.462295 & 0.086230 & 0,978967 & -0.194925 & 0.060229 \\
\hline $\mathrm{FF}$ & 0.941271 & -0.326959 & 0.084302 & 0.505199 & 0.842667 & -0.186241 \\
\hline Eigenvalues & 2.758329 & 3.980397 & 4 & 2.404429 & 1.513326 & 0.082245 \\
\hline \multirow[t]{2}{*}{ Expl Var } & 88.95822 & 30.55172 & 0.49006 & 80.11072 & 37.83314 & 2.05613 \\
\hline & \multicolumn{3}{|c|}{ 90\% Transient } & \multicolumn{3}{|c|}{$96 \%$ Take off } \\
\hline $\mathrm{T}$ & -0.575522 & 0.380707 & 0.723765 & -0.799819 & -0.343681 & 0.492111 \\
\hline $\mathrm{N}_{\mathrm{p}}$ & -0.780670 & 0.549097 & -0.298408 & 0.952288 & -0.109716 & 0.284796 \\
\hline ITT & -0.270345 & -0.912436 & 0.307203 & -0.951530 & 0.290448 & -0.101150 \\
\hline FF & 0.796407 & 0.503632 & 0.334799 & 0.109811 & 0.965017 & 0.238084 \\
\hline Eigenvalues & 1.648021 & 1.532631 & 0.819348 & 2.464031 & 1.145772 & 0.390198 \\
\hline Expl Var & 81.20054 & 38.31577 & 20.48369 & 81.60076 & 28.6443 & 9.75494 \\
\hline
\end{tabular}

According to PCA, there are four experimental fluctuations in the system. This is expressed in terms of the characteristic values (Eigenvalues) of each regime. Moreover, the direction of these oscillations is marked by a single factor in the three operating regimes. The initial operating regime shows a maximum variance of $89 \%$. Theoretically, as the operating regime increases, variables such as the measured revolutions progressively vary. However, this variable stabilizes in the maximum performance condition. Alternatively, 
the fuel flow variable shows a minimum value of $96 \%$, indicating that in this condition, this variable does not affect the disturbances of the system and that the only relevant variables that affect the variability are the revolutions $\left(\mathrm{N}_{\mathrm{p}}\right)$ delivered by the engine. It is also related to the ITT variable and the exergy of the engine. The engine behavior is related to the combustion of the mixture and the ITT temperature and, also, to the delivered power. Especially, to the engine revolutions $(\mathrm{Np})$ and torque $(\mathrm{T})$. This trend is maintained in all regimes. With the only exception that the fuel flow is relevant as a significant variable in the $65 \%$ Middle condition. This is probably because of the fuel gauge sensor that tends to be more sensitive at engine start than at cruising condition.

\subsection{Technical-Mechanical Inspection}

Finally, a technical-mechanical inspection is conducted to visualize coke and soot formation, cracks, material detachment, wear, color change, or material friction in the engine components as shown in Figure 9. The viscosity of the mixture affects the injection systems since it increases as a function of biodiesel content. This is verified in the inspection tests of this mechanical component. Coke formation on mechanical components for $25 \%$ of biodiesel in blends is also observed.

The confined section of the cooling devices is disassembled in the internal inspection of the combustion chamber. The inspection found minor fractures, calcination, and loss of thermal protection in the hot section. When observing the images, black stains are evidenced, which reflects the production of surface wear. Likewise, when inspecting the compressor rotor blades (NG) and power turbine rotor (NF), it is evident that there are no significant failures due to fractures or pitting. However, there is evidence of minor deformation in the blades, which do not show considerable impacts in their wear, but there is evidence of sulfidation and minor corrosion in this area, as shown in Figure 10.

Subsequently, no significant changes are evidenced in the inspection of the power turbine stator and turbine thermocouples. Especially due to the dilatation of components with relevant surface impacts. Likewise, the compressor stator is verified: no relevant changes in geometry due to dilatation or fractures are observed. However, slight concentrations and traces of overtemperature are observed, as shown in Figure 11.

The friction of the tip of the blades against the internal surface is evidenced in turbine rotor blades. This situation forces the relocation of the segments. It also demands to conduct a tolerance readjustment, in which the blades are polished to remove the molten metal due to friction. Finally, these are assembled assuring the established parameters. 


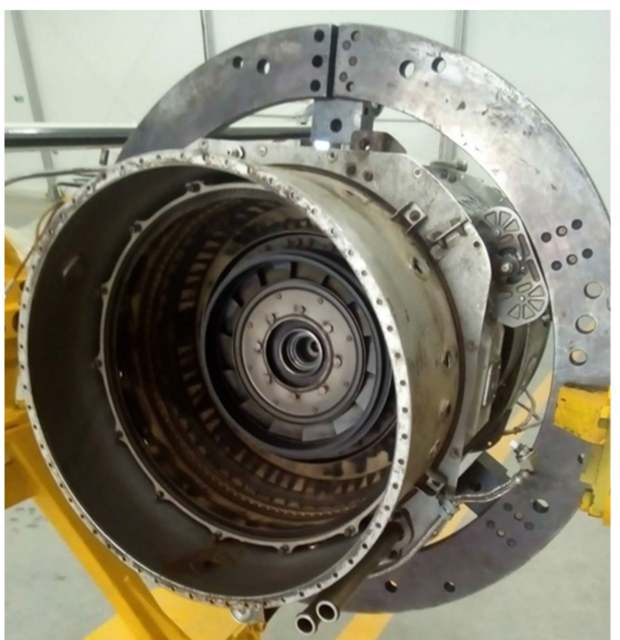

(a)

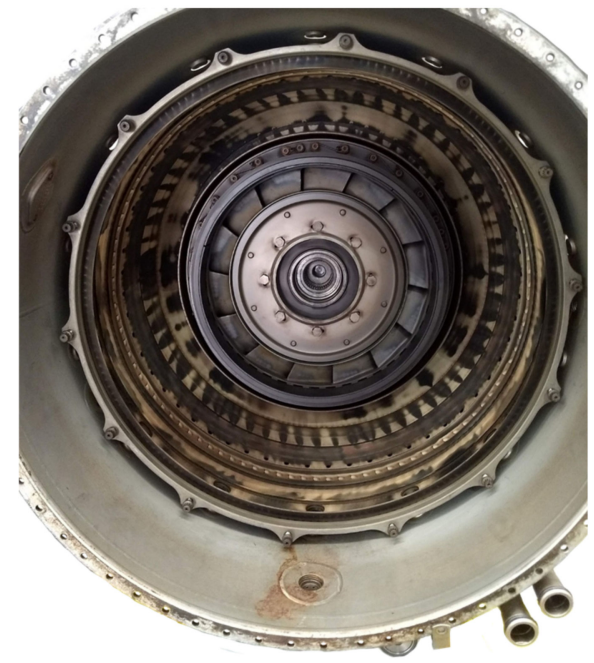

(c)

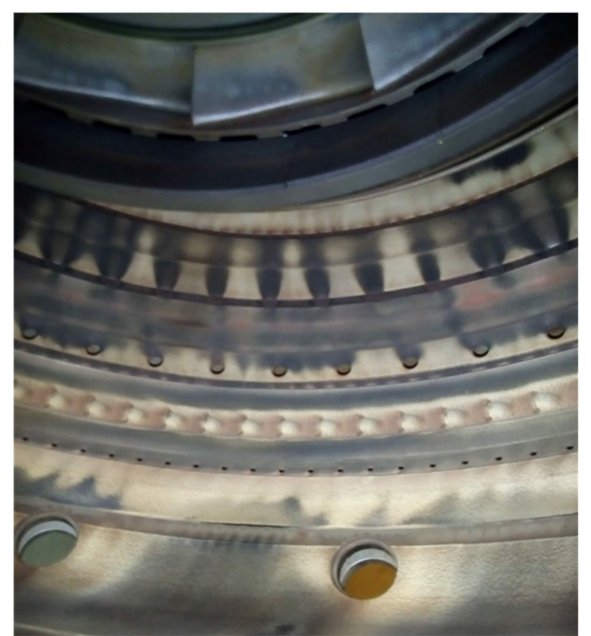

(b)

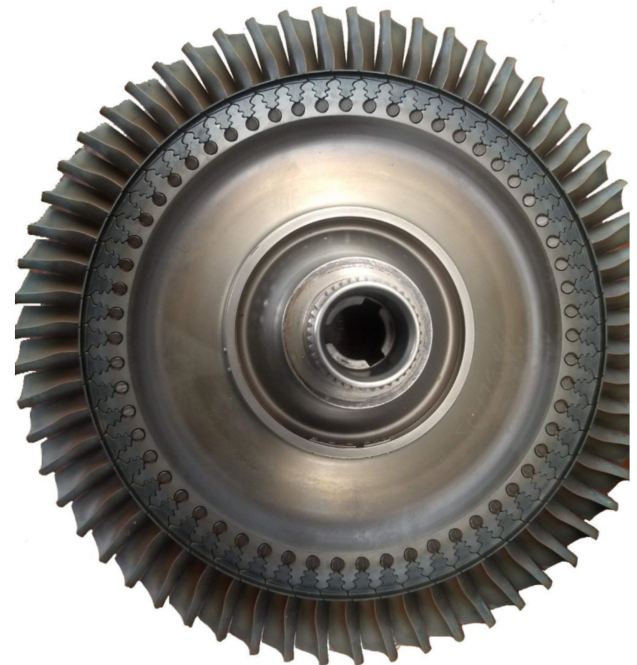

(d)

Figure 9. Engine components after evaluation tests with biodiesel and JETA-1 blends: (a) Internal Hot section (mounting on-field), (b) Stator, (c) Internal Hot section (Front view), (d) Turbine Wheel.

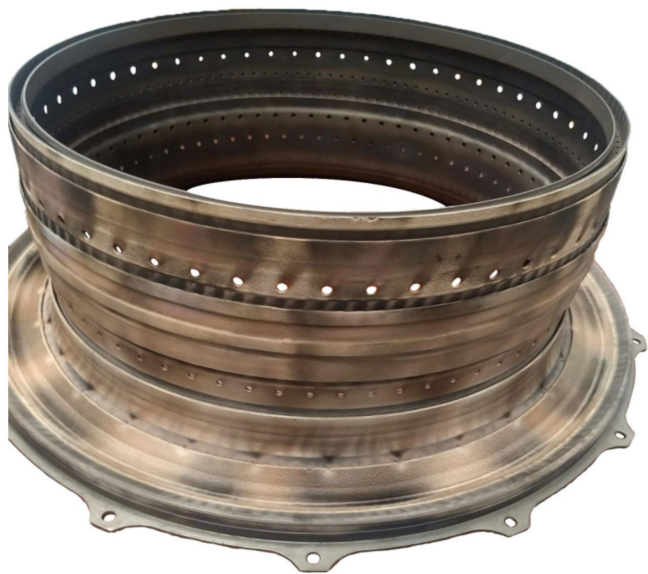

(a)

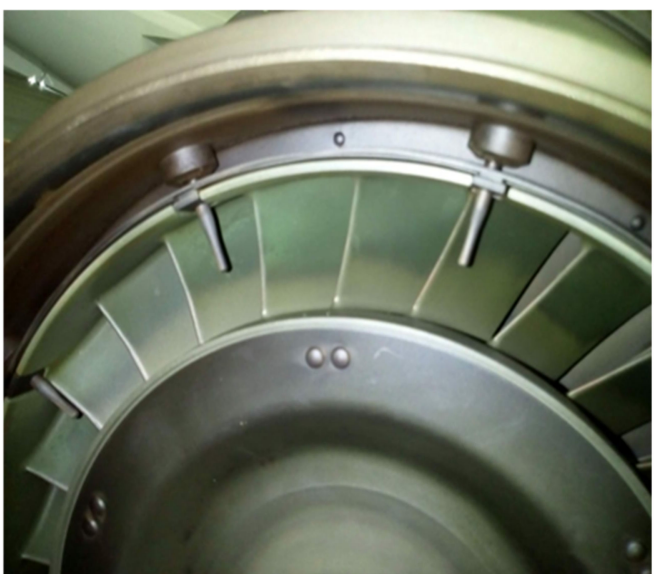

(b)

Figure 10. Engine components after evaluation tests with biodiesel and JETA-1 blends: (a) Compressor rotor blades, (b) Power turbine rotor. 


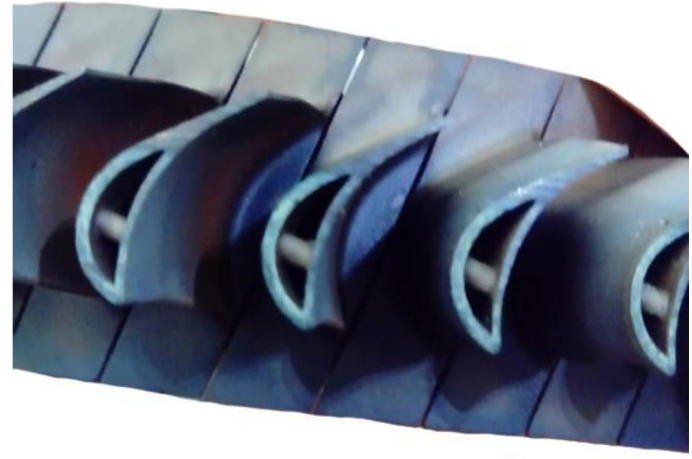

(a)

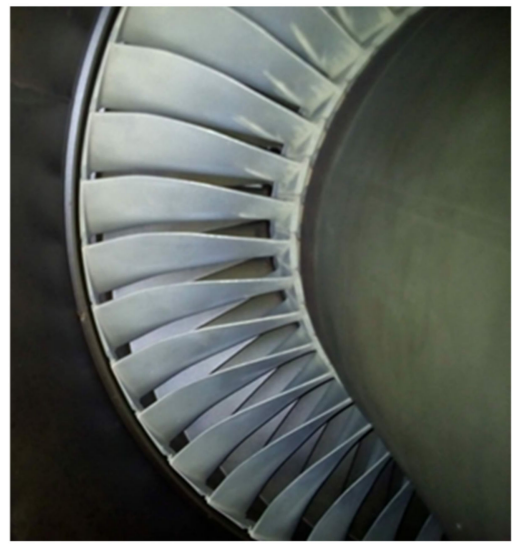

(b)

Figure 11. Engine components after evaluation tests with biodiesel and JETA-1 blends: (a) Turbine thermocouples, (b) External section of power turbine stator.

\section{Discussion}

The biofuel blends are suitable for operating at low altitudes: Physicochemical properties of blends allow their use in military aircraft engines, but the freezing point is too high for use in civil aviation. The experimental and numerical results of ITT are presented in Figure 12. In that figure, results are given for each blend against the operation regime (dash lines). Numerical results (continuous lines) are computed using the numerical software of the PT6A-61A engine in Bayona-Roa et al. [28]. The ITT variable is directly related to the combustion kinetics, but indirectly to the compression process. Hence, it gives an insight of the blend impact on the combustion process.

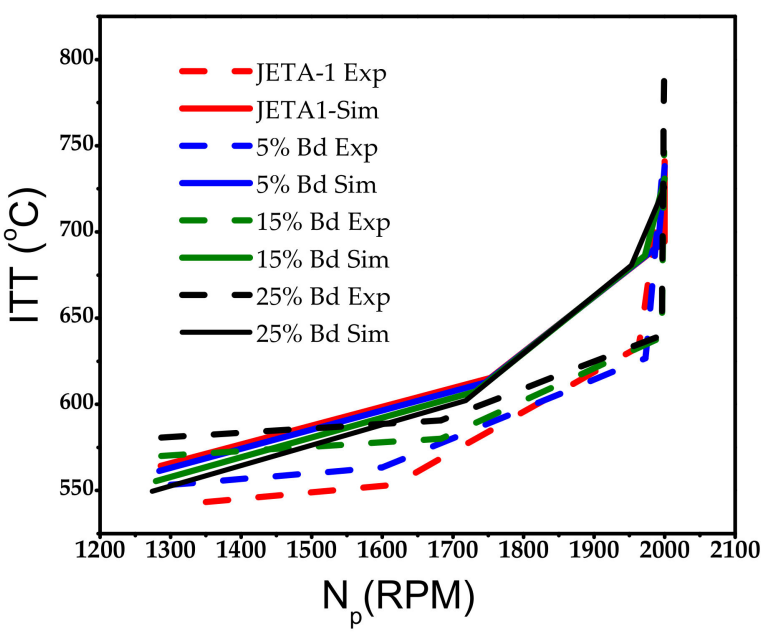

Figure 12. Comparison between experimental and numerical results: Experimental ITT (Dash Lines). Numerical ITT (Continuous Line) from Bayona-Roa et al. [13].

The differences in the experimental and simulation can be explained due to the ideal combustion model for blends in the numerical simulation. In a realistic operating condition, many variables affect this temperature between turbines, such variations in viscosity and density of blends, resulting in fluctuations during combustion and subsequently in the energy delivery of the engine. The operating limits of the ITT and engine speed are not exceeded. Typically, during start-up of PT6A-61A engines, the ITT generally rises to $1000{ }^{\circ} \mathrm{C}$ for $30 \mathrm{~s}$. In normal operation and cruise conditions, $800{ }^{\circ} \mathrm{C}$ is the normal operating temperature and finally, maximum temperatures of $850{ }^{\circ} \mathrm{C}$ are reached for a $5 \mathrm{~min}$ 
maximum allowable time during Takeoff. Thus, Biofuel blends are suitable for operating this type of engine: Critical conditions are not reached at the maximum performance $\mathrm{Np}$ condition. In the experimental results, the blended fuel provides highest ITTs when compared to computational results. It is also observed that the temperature difference arising between the fuel decreases with the higher loads. No temperature variation within the biodiesel blends at all regimes is observed. On the other hand, in the numerical simulations, we observe greater ITTs given by JETA-1. For that case, ITT depends greatly on the fuel blend: the maximum temperature of $760{ }^{\circ} \mathrm{C}$ is obtained with the Jet-A1 fuel, and the minimum of $700{ }^{\circ} \mathrm{C}$, approximately, is obtained with the $25 \%$ biodiesel blend. There is even an $80^{\circ} \mathrm{C}$ temperature difference between the Jet-A 1 fuel and the $25 \%$ biodiesel fuel blend at the Idle regime. Regardless of the fuel type, the temperature results never exceed a value of $800{ }^{\circ} \mathrm{C}$ for the full-throttle operation. That condition agrees well with those reported in the manual: in any case, the maximum ITT complains with the structural safety.

\section{Conclusions}

Experimental analysis of the behavior of the PT6-A61A engine with conventional JETA1 and Biodiesel FAME fuel blends have been achieved. Experimental results demonstrate a correct engine function. Quantities such as torque, propeller revolutions, inter turbine temperature, and fuel flow guarantee the engine performance described in the operating manual. Results at Min Idle 65\%, Transient 75\%, Transient 90\%, Transient $96 \%$, and Take-off regimes guarantee the manufacturer required performance. That results in the approval of the use of biodiesel in the PT6A-61A engine fuel. However, the freezing point of fuel blends is still not suitable for civil aviation, as it has been found to be above the optimal value of $-47^{\circ} \mathrm{C}$. However, for military aviation the blends are suitable for operating PT6A-61A engines, where the maximum altitudes are 12,000 ft. In terms of operation, the mixtures portray a reduction in their calorific value according to the JETA-1 reference, which minimally compromises performance. However, the fuel blend viscosity has been found to affect the injection systems of the engine. In terms of the thermal and mechanical variables, both the delivered propeller speed and torque have been higher in the case of the biofuel blends operation. That indicates that the exergy of the blends has been higher. Which could be explained due to subtle changes in the carbon chains and the $\mathrm{C} / \mathrm{H}$ and $\mathrm{C} / \mathrm{O}$ ratio of the mixtures. Indeed, that has been confirmed by spectroscopic analysis, affecting the combustion parameters and mechanical performance. Finally, PCA of the experimental data has indicated that the system is subject to four fluctuations, associated with possible vibration effects and significant variables in the combustion chamber. That can be explained by the complexity of the reaction kinetics for mixtures of paraffinic compounds and fatty acids and their effects on the reaction heat. Thermal performance depends on the energy values of the fuels. For instance, over the \% of biodiesel that directly decreases the lower and higher heating values. That effect is critical during the ignition process, which has required more energy to begin the combustion process due to the saturated fatty acids addition. In this sense, the energy and exergetic efficiency can be compromised. Especially, in the more demanding regimes such as take-off since fuel consumption has resulted proportionally higher. The inspection results do not show engine damages, nor to injectors or turbine blades. Emission measurements could not be performed. However, a reduction in emissions is expected to occur with biodiesel operation.

As a future work, kinetic combustion models can be coupled to the present model in order to determine the added heat and the production of gases. It is also possible to analyze the exhaust gases and the engine control: torque control, pressure control, but especially, combustion control in the experimental behavior. Other types of engines operating with biodiesel blends are necessary to be tested in order to achieve a general investigation of the fossil fuel substitution in the aeronautic sector. 
Author Contributions: Conceptualization, A.R.G.C.; methodology, A.R.G.C., N.J.A. and V.S.L.; software, A.R.G.C. and C.B.-R.; validation, A.R.G.C., M.A.M.B. and C.B.-R.; formal analysis, A.R.G.C., M.A.M.B. and C.B.-R.; investigation, A.R.G.C., M.A.M.B. and D.C.; resources, C.B. and D.C.; data curation, A.R.G.C.; writing-original draft preparation, A.R.G.C.; writing-review and editing, A.R.G.C. and C.B.-R.; visualization, A.R.G.C. and C.B.-R.; supervision, V.S.L.; project administration, M.L. and V.S.L.; funding acquisition, M.L. All authors have read and agreed to the published version of the manuscript.

Funding: This research was funded by Departamento Administrativo de Ciencia, Tecnología e Innovación through the "Evaluación del comportamiento de mezclas de biocombustibles colombianos en turbinas aeronáuticas" project. Contract \# 80740-728-2020.

Institutional Review Board Statement: Not applicable.

Informed Consent Statement: Not applicable.

Data Availability Statement: Exclude this statement.

Acknowledgments: The authors express their gratitude to the ECCI University, Colombian Air Force and institutions such as Terpel S.A and BioD S.A for conducting physicochemical characterization. Especially to Angela Paola Sánchez and the technical and operational team of the Colombian Air Force.

Conflicts of Interest: The authors declare no conflict of interest.

\section{References}

1. Sehra, A.K.; Whitlow, W. Propulsion and power for 21st century aviation. Prog. Aerosp. Sci. 2004, 40, 199-235. [CrossRef]

2. Yim, S.H.L.; Lee, G.L.; Lee, I.H.; Allroggen, F.; Ashok, A.; Caiazzo, F.; Eastham, S.D.; Malina, R.; Barrett, S.R.H. Global, regional and local health impacts of civil aviation emissions. Environ. Res. Lett. 2015, 10, 1-12. [CrossRef]

3. Alonso, D.M.; Bond, J.Q.; Dumesic, J.A. Catalytic conversion of biomass to biofuels. Green Chem. 2010, 12, 1493-1513. [CrossRef]

4. Rochelle, D.; Najafi, H. A review of the effect of biodiesel on gas turbine emissions and performance. Renew. Sustain. Energy Rev. 2019, 105, 129-137. [CrossRef]

5. Lawer-Yolar, G.; Dawson-Andoh, B.; Atta-Obeng, E. Synthesis of Biodiesel from Tall Oil Fatty Acids by Homogeneous and Heterogeneous Catalysis. Sustain. Chem. 2021, 2, 206-221. [CrossRef]

6. Gaide, I.; Makareviciene, V.; Sendzikiene, E.; Kazancev, K. Natural Rocks-Heterogeneous Catalysts for Oil Transesterification in Biodiesel Synthesis. Catalysts 2021, 11, 384. [CrossRef]

7. Singh, D.; Sharma, D.; Soni, S.L.; Sharma, S.; Kumar Sharma, P.; Jhalani, A. A review on feedstocks, production processes, and yield for different generations of biodiesel. Fuel 2020, 262, 116553. [CrossRef]

8. Mekhilef, S.; Siga, S.; Saidur, R. A review on palm oil biodiesel as a source of renewable fuel. Renew. Sustain. Energy Rev. 2011, 15, 1937-1949. [CrossRef]

9. Gutiérrez-López, A.N.; Mena-Cervantes, V.Y.; García-Solares, S.M.; Vazquez-Arenas, J.; Hernández-Altamirano, R. $\mathrm{NaFeTiO}_{4} / \mathrm{Fe}_{2} \mathrm{O}_{3}-\mathrm{FeTiO}_{3}$ as heterogeneous catalyst towards a cleaner and sustainable biodiesel production from Jatropha curcas L. oil. J. Clean. Prod. 2021, 304, 127106. [CrossRef]

10. Ayoola, A.A.; Hymore, F.K.; Omonhinmin, C.A.; Babalola, P.O.; Fayomi, O.S.I.; Olawole, O.C.; Olawepo, A.V.; Babalola, A. Response surface methodology and artificial neural network analysis of crude palm kernel oil biodiesel production. Chem. Data Collect. 2020, 28, 100478. [CrossRef]

11. Shahid, E.M.; Jamal, Y. A review of biodiesel as vehicular fuel. Renew. Sustain. Energy Rev. 2008, 12, 2484-2494. [CrossRef]

12. Hoekman, S.K.; Broch, A.; Robbins, C.; Ceniceros, E.; Natarajan, M. Review of biodiesel composition, properties, and specifications. Renew. Sustain. Energy Rev. 2012, 16, 143-169. [CrossRef]

13. Lapuerta, M.; Armas, O.; Rodríguez-Fernández, J. Effect of biodiesel fuels on diesel engine emissions. Prog. Energy Combust. Sci. 2008, 34, 198-223. [CrossRef]

14. Kohse-Höinghaus, K.; Oßwald, P.; Cool, T.A.; Kasper, T.; Hansen, N.; Qi, F.; Westbrook, C.K.; Westmoreland, P.R. Biofuel Combustion Chemistry: From Ethanol to Biodiesel. Angew. Chem. Int. Ed. 2010, 49, 3572-3597. [CrossRef]

15. Potrč, S.; Čuček, L.; Martin, M.; Kravanja, Z. Synthesis of European Union Biorefinery Supply Networks Considering Sustainability Objectives. Processes 2020, 8, 1588. [CrossRef]

16. Bounnit, T.; Saadaoui, I.; Rasheed, R.; Schipper, K.; Al Muraikhi, M.; Al Jabri, H. Sustainable Production of Nannochloris atomus Biomass Towards Biodiesel Production. Sustainability 2020, 12, 2008. [CrossRef]

17. Razzaq, L.; Farooq, M.; Mujtaba, M.A.; Sher, F.; Farhan, M.; Hassan, M.T.; Soudagar, M.E.M.; Atabani, A.E.; Kalam, M.A.; Imran, M. Modeling Viscosity and Density of Ethanol-Diesel-Biodiesel Ternary Blends for Sustainable Environment. Sustainability 2020, 12, 5186. [CrossRef]

18. Talero, G.; Bayona-Roa, C.; Munoz, G.; Galindo, M.; Silva, V.; Pava, J.M.; Lopez, M. Experimental methodology and facility for the J69-engine performance and emissions evaluation using jet A1 and biodiesel blends. Energies 2019, 12, 4530. [CrossRef] 
19. Talero, G.; Bayona-Roa, C.; Silva, V.; Mayorga, M.; Pava, J.; Lopez, M. Biodiesel substitution in a J69 aeronautic turbine engine: An experimental assessment of the effects on energy efficiency, technical performance and emissions. Sustain. Energy Technol. Assess. 2020, 40, 1-14. [CrossRef]

20. Yilmaz, N.; Vigil, F.M. Potential use of a blend of diesel, biodiesel, alcohols and vegetable oil in compression ignition engines. Fuel 2014, 124, 168-172. [CrossRef]

21. Seyam, S.; Dincer, I.; Agelin-Chaab, M. Novel hybrid aircraft propulsion systems using hydrogen, methane, methanol, ethanol and dimethyl ether as alternative fuels. Energy Convers. Manag. 2021, 238, 114172. [CrossRef]

22. Babazadeh, R. Optimal design and planning of biodiesel supply chain considering non-edible feedstock. Renew. Sustain. Energy Rev. 2017, 75, 1-12. [CrossRef]

23. Van der Horst, D.; Vermeylen, S. Spatial scale and social impacts of biofuel production. Biomass Bioenergy 2011, 35, $2435-2443$. [CrossRef]

24. IPCC. Climate Change 2014: Synthesis Report. Contribution of Working Groups I, II and III to the Fifth Assessment Report of the Intergovernmental Panel on Climate Change; Pachauri, R.K., Meyer, L.A., Eds.; IPCC: Geneva, Switzerland, 2014.

25. Mayorga Betancourt, M.A.; López Santamaria, C.A.; López Gómez, M.; Gonzalez Caranton, A.R. Experimental analysis of biodiesel synthesis from palm kernel oil: Empirical model and surface response variables. React. Kinet. Mech. Catal. 2020, 131, 297-317. [CrossRef]

26. Yang, H.-H.; Chien, S.-M.; Lo, M.-Y.; Lan, J.C.-W.; Lu, W.-C.; Ku, Y.-Y. Effects of biodiesel on emissions of regulated air pollutants and polycyclic aromatic hydrocarbons under engine durability testing. Atmos. Environ. 2007, 41, 7232-7240. [CrossRef]

27. Cao, P.; Dubé, M.A.; Tremblay, A.Y. High-purity fatty acid methyl ester production from canola, soybean, palm, and yellow grease lipids by means of a membrane reactor. Biomass Bioenergy 2008, 32, 1028-1036. [CrossRef]

28. Bayona-Roa, C.; Solís-Chaves, J.S.; Bonilla, J.; Rodriguez-Melendez, A.G.; Castellanos, D. Computational simulation of PT6A gas turbine engine operating with different blends of biodiesel-a transient-response analysis. Energies 2019, 12, 4258. [CrossRef]

29. Coban, K.; Şöhret, Y.; Colpan, C.O.; Karakoç, T.H. Exergetic and exergoeconomic assessment of a small-scale turbojet fuelled with biodiesel. Energy 2017, 140, 1358-1367. [CrossRef]

30. PT6A Small Series Heavy Maintenance Course. Available online: https://fdocuments.in/document/curso-pt6a-small-series.html (accessed on 2 March 2021).

31. PT6A-60 Series Training Manual, Quebec. Available online: https://mikeklochcfi.files.wordpress.com/2018/08/training-pt6a-60 -series.pdf (accessed on 2 March 2021).

32. European Rotorcraft Forum 33 Kazan Tatarstan, Russia 11-13 September 2007. Available online: https://dspace-erf.nlr.nl/ xmlui / bitstream/handle/20.500.11881/237/Pratt\%20\&\%20Whitney\%20Canada\%20Turboshaft\%20Engines\%20Product\%20 .pdf?sequence $=1$ (accessed on 13 January 2021).

33. Pratt \& Whitney. PT6A Familiarisacion \& Caza Fallas. Prad \& Whitney Canada Corporation (Only for Training); Pratt \& Whitney: East Hartford, CT, USA, 2000; pp. 1-110.

34. PT6A Training Course, Quebec. Available online: http://www.mautone.eng.br/apostilas/propulsao1/PT6\%20Training\%20 Manual.pdf (accessed on 2 March 2021).

35. Yoshinaka, T.; Thue, K.S. A Cost-Effective Performance Development of the PT6A-65 Turboprop Compressor; ASME: New York, NY, USA, 1985.

36. Saintsbury, J.A.; Sampath, P. The potential impact of future fuels on small gas turbine engines. In Proceedings of the ASME 1982 International Gas Turbine Conference and Exhibit, ASME Turbo Expo, London, UK, 8-12 April 1982; Volume 3.

37. Chaves, J.S.S.; Rojas, J.F.B.; Vargas, C.G.Q.; Acuña, N.A.J.; Alba, Á.P.S. Diseño e implementación de un control mecánico con cables tipo Push-Pull para un banco de pruebas en tierra de motores PT6. Cienc. Y Poder Aéreo 2020, 15, 135-151. [CrossRef]

38. Gonzalez Caranton, A.R.; da Silva Pinto, J.C.C.; Stavale, F.; Barreto, J.; Schmal, M. Statistical analysis of the catalytic synthesis of Vinyl acetate over Pd-Cu/ $\mathrm{ZrO}_{2}$ nanostructured based catalysts. Catal. Today 2018, 344, 108-117. [CrossRef]

39. Attia, N.K.; Abdel Kader, E.A.; ElDiwani, G.; Hussein, H.S.; El-Araby, R. Evaluation of Blending of Lowest Emission Biodiesel with Jet A for Producing Aviation Biofuels. Util. Manag. Bioresour. 2018. [CrossRef]

40. Da Silva, J.Q.; Santos, D.Q.; Fabris, J.D.; Harter, L.V.L.; Chagas, S.P. Light biodiesel from macaúba and palm kernel: Properties of their blends with fossil kerosene in the perspective of an alternative aviation fuel. Renew. Energy 2020, 151, 426-433. [CrossRef]

41. Chuck, C.J.; Donnelly, J. The compatibility of potential bioderived fuels with Jet A-1 aviation kerosene. Appl. Energy 2014, 118, 83-91. [CrossRef]

42. Solmaz, H.; Yamik, H.; Içingür, Y.; Calam, A. Investigation of the effects of civil aviation fuel Jet A1 blends on diesel engine performance and emission characteristics. Indian J. Eng. Mater. Sci. 2014, 21, 200-206.

43. Kim, Y.; Thomas, A.E.; Robichaud, D.J.; Iisa, K.; St. John, P.C.; Etz, B.D.; Fioroni, G.M.; Dutta, A.; McCormick, R.L.; Mukarakate, C.; et al. A perspective on biomass-derived biofuels: From catalyst design principles to fuel properties. J. Hazard. Mater. 2020, 400, 1-11. [CrossRef]

44. Chiatti, G.; Chiavola, O.; Palmieri, F. Impact on Combustion and Emissions of Jet Fuel as Additive in Diesel Engine Fueled with Blends of Petrol Diesel, Renewable Diesel and Waste Cooking Oil Biodiesel. Energies 2019, 12, 2488. [CrossRef]

45. Anderson, A.; Karthikeyan, A.; Kumar, C.R.; Ramachandran, S.; Praveenkumar, T.R. Lowest emission sustainable aviation biofuels as the potential replacement for the Jet-A fuels. Aircr. Eng. Aerosp. Technol. 2020. [CrossRef] 
46. Justin Sundararaj, A.; Guna, K.R.; William, M. Experimental investigation of the effect of temperature on ignition of modified kerosene. Int. J. Engine Res. 2021. [CrossRef]

47. Dagaut, P.; Gail, S. Chemical kinetic study of the effect of a biofuel additive on Jet-A1 combustion. J. Phys. Chem. A 2007, 111, 3992-4000. [CrossRef]

48. Edwards, T. Surrogate Mixtures to Represent Complex Introduction. J. Propuls. Power 2001, 17, 461-466. [CrossRef]

49. Chong, C.T.; Hochgreb, S. Measurements of laminar flame speeds of liquid fuels: Jet-A1, diesel, palm methyl esters and blends using particle imaging velocimetry (PIV). Proc. Combust. Inst. 2011, 33, 979-986. [CrossRef]

50. Revathy, T.; Jayasri, M.A.; Suthindhiran, K. Biodegradation of PAHs by Burkholderia sp. VITRSB1 Isolated from Marine Sediments. Scientifica 2015, 2015, 1-9. [CrossRef] [PubMed]

51. Lam, M.K.; Jamalluddin, N.A.; Lee, K.T. Production of biodiesel using palm oil. In Biomass, Biofuels, Biochemicals: Biofuels: Alternative Feedstocks and Conversion Processes for the Production of Liquid and Gaseous Biofuels; Elsevier: Amsterdam, The Netherlands, 2019.

52. Zhang, W.-B. Review on analysis of biodiesel with infrared spectroscopy. Renew. Sustain. Energy Rev. 2012, 16, 6048-6058. [CrossRef]

53. Joven, J.M.O.; Gadian, J.T.; Perez, M.A.; Caingles, J.G.; Mansalaynon, A.P.; Ido, A.L.; Arazo, R.O. Optimized ultrasonic-assisted oil extraction and biodiesel production from the seeds of Maesopsis eminii. Ind. Crop. Prod. 2020, 155, 1-10. [CrossRef]

54. Kong, C.; Ki, J.; Chung, S. Performance simulation of a turboprop engine for basic trainer. Ksme Int. J. 2002, 16, 839-850. [CrossRef]

55. Gad, M.S.; Ismail, M.A. Effect of waste cooking oil biodiesel blending with gasoline and kerosene on diesel engine performance, emissions and combustion characteristics. Process Saf. Environ. Prot. 2021, 149, 1-10. [CrossRef]

56. Agarwal, A.K. Biofuels (alcohols and biodiesel) applications as fuels for internal combustion engines. Prog. Energy Combust. Sci. 2007, 33, 233-271. [CrossRef]

57. Jankowski, A.; Kowalski, M. Start-up processes' efficiency of turbine jet engines. J. Konbin 2016, 40, 63-82. [CrossRef]

58. Ekici, S.; Altuntas, O.; Açikkalp, E.; Sogut, M.Z.; Karakoc, T.H. Assessment of thermodynamic performance and exergetic sustainability of turboprop engine using mixture of kerosene and methanol. Int. J. Exergy 2016, 19. [CrossRef]

59. Devi, B.; Venkatesh, S.; Vimal, R.; Praveenkumar, T.R. Influence of high oxygenated biofuels on micro-gas turbine engine for reduced emission. Aircr. Eng. Aerosp. Technol. 2020. Ahead-of-print. [CrossRef]

60. Balli, O. Advanced exergy analyses to evaluate the performance of a military aircraft turbojet engine (TJE) with afterburner system: Splitting exergy destruction into unavoidable/avoidable and endogenous/exogenous. Appl. Therm. Eng. 2017, 111, 152-169. [CrossRef]

61. Silva, V.T.; Bringhenti, C.; Tomita, J.T.; Fontes, A.F. A Propeller Model for Steady-State and Transient Performance Prediction of Turboprop and Counter-Rotating Open Rotor Engines. J. Eng. Gas Turbines Power 2018, 140. [CrossRef]

62. Yin, F.; Rao, A.G. Off-Design Performance of an Interstage Turbine Burner Turbofan Engine. J. Eng. Gas Turbines Power 2017, 139. [CrossRef] 